https://helda.helsinki.fi

\title{
Synderesis in late medieval philosophy and the Wittenberg reformers
}

\author{
Kärkkäinen, Pekka
}

2012

Kärkkäinen , P 2012 , ' Synderesis in late medieval philosophy and the Wittenberg reformers

' , British Journal for the History of Philosophy , vol. 20 , no. 5 , pp. 881-901 . https://doi.org/10.1080/09608788.2012.

http://hdl.handle.net/10138/179238

https://doi.org/10.1080/09608788.2012.718866

acceptedVersion

Downloaded from Helda, University of Helsinki institutional repository.

This is an electronic reprint of the original article.

This reprint may differ from the original in pagination and typographic detail.

Please cite the original version. 
This is an Accepted Manuscript an article published in the British Journal for the History of Philosophy 06/09/2012, available online at: http://www.tandfonline.com/doi/abs/10.1080/09608788.2012.718866

Synderesis in Late Medieval Philosophy and the Wittenberg Reformers

Pekka Kärkkäinen

\begin{abstract}
The present article discusses the concept of synderesis in the late medieval universities of Erfurt and Leipzig and its the later developments in Wittenberg. The comparison between Bartholomaeus Arnoldi of Usingen in Erfurt and Johannes Peyligk in Leipzig shows that school traditions played an important role in the exposition of synderesis by the late medieval scholastic natural philosophers. However, Jodocus Trutfetter's example warns against overemphasising the importance of the school traditions and reminds us of the manifold history of medieval discussions on synderesis, which were more or less familiar to many authors of this period. Finally, the diverse references to synderesis in the texts of Martin Luther, Johannes Bernhardi of Feldkirch and Philip Melanchthon reveal no uniform relationship with late medieval discussions, but rather indicate various ways of adopting scholastic ideas and transforming them in the context of humanist and reformation thinking.
\end{abstract}


Synderesis: from the Late Medieval Viae to the Wittenberg Reformers

1. Introduction

In 1977 Michael Baylor published a work entitled 'Action and Person, Conscience in Late Scholasticism and the Young Luther'. In it, he examines the diverse late medieval theories concerning notions of synderesis, conscience and practical reason, which are concepts commonly used to describe the psychological process of forming moral judgements. Furthermore, he explains Martin Luther's theological elaboration of these theories. One conclusion of Baylor's study is, generally speaking, that several of Luther's sayings regarding the conscience and other related entities are deeply rooted in medieval scholasticism. Another important point is Baylor's analysis of the disappearence of the concept of synderesis in Luther's mature theology, where the heightened status of conscience plays a significant role. ${ }^{1}$

Since then, two notable studies have applied Baylor's main results to the analysis of the concept of conscience in the history of theology and philosophy, respectively. ${ }^{2}$ The studies leave it still open how various late medieval theories of synderesis were received by early Lutheran theologians and philosophers. For answering the question in detail, a contextual approach to the philosophy and theology of early sixteenth century Germany seems necessary.

\footnotetext{
${ }^{1}$ M. Baylor, Action and Person (Leiden: Brill, 1977).

${ }^{2}$ R. C. Zachmann, The Assurance of Faith (Louisville: Westminster John Knox Press, 1993); D. Langston, Conscience and Other Virtues (University Park: The Pennsylvania State University Press, 2001) 71-77. On humanist notions of conscience, see also R. B. Hein, 'Gewissen' bei Adrian of Utrecht (Hadrian VI.), Erasmus von Rotterdam und Thomas More (Münster: Lit Verlag, 1999).
} 
However, there is no final agreement on the controversial issue of whether it is possible to find a exhaustive definition of the late medieval schools of the via antiqua, via moder$n a$ and their different subsets. ${ }^{3}$ For the present purposes it is enough to state that at the end of the fifteenth century there were philosophers and theologians who describe their position, and also those of their contemporaries, by using expressions such as via antiqua and via moderna (or antiqui and moderni). Those who find themselves among the via antiqua tend to base their teaching exclusively on a certain tradition, where the method (lat. processus or expositio) of authors like Aquinas and Scotus are largely followed, and where some of the more recent authors, like William of Ockham and several others, are ignored. The philosophers and theologians who preferred the method of more recent writers, such as that of William of Ockham, Pierre d'Ailly or Marsilius of Inghen, called themselves the moderni. Some universities preferred one or the other school, such as the university of Erfurt where teaching was given exclusively according to the via moderna, but in other universities like Tübingen chairs existed for both the via antiqua and via moderna. ${ }^{4}$

The focus of the present article is on the concept of synderesis, which was given diverse functions in the process of forming a moral judgement by different authors. The differences between the traditions of thought are most conspicuous in the discussions concerning synderesis. Unlike Baylor, I will not discuss Luther's views in detail. Rather, I try to widen the knowledge of Luther's intellectual context by looking at the teaching of moral psycholo-

${ }^{3}$ On the problems of defining the late medieval schools, see M. J.F.M. Hoenen, 'Via Antiqua and Via Moderna in the Fifteenth Century: Doctrinal, Institutional, and Church Political Factors in the Wegestreit', in The Medieval Heritage in Early Modern Metaphysics and Modal Theory, edited by L. Nielsen and R. Friedman (Dordrecht: Kluwer, 2003) 9-36. ${ }^{4}$ Hoenen (2003) 13-16; H. A. Oberman, 'Via antiqua and Via Moderna: Late Medieval Prolegomena to Early Reformation Thought', Journal of the History of Ideas, 48 (1987) 2340, esp. 24. 
gy in his immediate surroundings. On one hand, this includes two universities: the first is Luther's alma mater, the university of Erfurt, which represented the tradition of the via moder$n a$, and the second is its rival, the university of Leipzig, which was at the time the most important centre of the Thomist via antiqua in that part of Germany. ${ }^{5}$ On the other hand, I will briefly discuss later developments concerning the concept of synderesis in Wittenberg, whose history was closely connected with both Erfurt and Leipzig.

2. Peyligk and Usingen: Affective and Cognitive Traditions

The extant sources provide us with a unique opportunity to compare the theories of moral psychology in Erfurt and Leipzig. Two textbooks on natural philosophy, one written in Leipzig and another in Erfurt, happen to both be written as commentaries on the same text. The base text is a compendium or a short tractate of natural philosophy entitled Parvulus philosophiae naturalis, probably written by Petrus Gerticz of Dresden (d. 1421). The Erfurt and Leipzig commentaries were even published in the same year of 1499 and apparently were also written at the same time. ${ }^{6}$

${ }^{5}$ Götz-Rüdiger Tewes has quite convincingly shown that an active confrontation occurred in the late fifteenth century between these two universities, at the core of which was the difference between the via antiqua and via moderna. See G.-R. Tewes, 'Die Erfurter Nominalisten und ihre thomistischen Widersacher in Köln, Leipzig und Wittenberg. Ein Beitrag zum deutschen Humanismus am Vorabend der Reformation' in Die Bibliotheca Amploni$a n a$, edited by A. Speer (Berlin: Walter de Gruyter, 1995) 447-88.

${ }^{6}$ Johannes Peyligk, Philosophie naturalis compendium [Compendium] (Leipzig: Melchior Lotter, 1499); Bartholomaeus Arnoldi de Usingen, Parvulus philosophie naturalis [Parvulus] (Leipzig: Wolfgang Stöckel, 1499). These works are available as digitized reproductions in the Wolfenbüttel Digital Library of the Herzog August Bibliothek, Wolfenbüttel (http://www.hab.de/bibliothek/wdb/). On Petrus, see S. Lalla, Secundum viam modernam: ontologischer Nominalismus bei Bartholomäus Arnoldi von Usingen (Würzburg: Königshausen \& Neumann, 2003) 78-82. 
The author of the Leipzig commentary was Johannes Peyligk, a Thomist philosopher who otherwise remains unknown to us. The author of the Erfurtian commentary was a far more well-known figure: Bartholomaeus Arnoldi, usually known as Usingen according to his birthplace. He was a respected figure in the Faculty of Arts at the university of Erfurt, but has been mostly known as Luther's teacher and fellow Augustinian, as well as an important opponent of the Reformation. ${ }^{7}$ Peyligk notes straight away in the title of his work that his intention is to follow the teachings of St. Thomas Aquinas and Giles of Rome. ${ }^{8}$ The latter was at that time considered to be the most significant theologian of the Augustinian order. ${ }^{9}$

Peyligk's treatise thus reveals in its very first lines a firm adherence to the via antiqua. Usingen, on the contrary, is a typical example of a philosopher coming from the tradition of the via moderna, although he often presents the viewpoints of all the contemporaneous schools of thought.

Considerable similarities exist between the views of these two thinkers, but also remarkable differences. Both accept the idea that the most universal principles of morality are accessible to all human beings through a faculty of the human soul called synderesis. Because of the generality of these principles, there is no possibility of error in the operation of synderesis. The error in moral judgement arises from other sources. ${ }^{10}$

How synderesis functions is, however, described differently by these two authors. Peyligk defines synderesis as a capability of the rational soul, but it is an affective rather than cognitive power:

\footnotetext{
${ }^{7}$ On Usingen's life, see Lalla (2003) 15-22.

${ }^{8}$ Peyligk, Compendium, fol. $1^{\mathrm{r}}$.

${ }^{9}$ On the authority of Giles of Rome, see A. Zumkeller, Erbsünde, Gnade, Rechtfertigung und Verdienst nach der Lehre der Erfurter Augustinertheologen des Spätmittelalters (Würzburg: Augustinus, 1984) 432-7.

${ }^{10}$ Peyligk, Compendium, fol. P1 ${ }^{\mathrm{v}}$; Usingen, Parvulus, fol. $119^{\mathrm{r}}$.
} 
Synderesis is an affective power and the theologians call it natural will. Conscience is a cognitive power and the theologians call it the natural power of judgement...The definition of synderesis is: synderesis is a motive power of the rational soul, which naturally tends towards higher things, moves and stimulates towards the good and abhors evil. 'Motive power' in the definition reveals to which class of powers it belongs, i.e. to motive powers. 'Naturally tends' refers to the permanent conversion of synderesis to the good, which is by no means distorted by sin and which is based on the universal principles of morality. These principles derive immediately from natural law, which is immutable. ${ }^{11}$

The purpose of synderesis is, according to Peyligk, to direct the human being towards good and away from evil. It follows the direction of the universal principles of moral reasoning, which derive immediately from natural law and are therefore by nature immutable. Peyligk does not give any concrete examples of these first principles of morality, but his focus is clearly not on the cognitive contents of these principles, but rather on the capability of synderesis to direct the soul towards the universal good.

Despite the above-mentioned Thomist 'confession' at the beginning of his treatise, Peyligk does not follow Aquinas in this particular matter, but other authorities instead. These

${ }^{11}$ Peyligk, Compendium, fol. $\mathrm{P}^{\mathrm{v}}$ : 'Sinderesis est vis affectiva dicta a theologis voluntas naturalis. Conscientia est vis cognitiva dicta a theologis naturale iudicatorium...Sinderisis sic definitur: est vis motiva animae rationalis, quae nata est figi in superioribus, naturaliter movens et stimulans ad bonum et abhorrens mali. In qua definitione cum dicitur 'vis motiva' ostenditur de quo genere potentiarum animae sit, quia de genere motivarum. Deinde cum dicit 'quae nata est figi' innuitur indelibilis conversio sinderisis ad bonum, nullatenus per peccatum obliquabilis, ex eo quod adhaeret primis et universalibus principiis moralibus, quae immediate derivantur a lege naturae quae immutabilis est'. 
include Bonaventure and a textbook on natural philosophy called Summa naturalium, which was one of Peyligk's immediate sources. ${ }^{12}$ However, Peyligk is aware of Aquinas's definition of synderesis which defines it as a disposition rather than a power. Peyligk admits that there exists an innate disposition to know the principles of moral reasoning, which is called, and is understood by Aquinas, as synderesis. Hence Peyligk tries to incorporate Aquinas's view into the picture by adopting his purely cognitive definition. Peyligk considers Aquinas's view of synderesis as if it would be meant to explain only an aspect of the whole concept, although Aquinas does not at all assign to synderesis the function of moving the soul towards good and away from evil. There is, however, the idea of a movement towards the highest good in Aquinas's thinking, but the function of synderesis is merely to provide some cognitive contents in order to facilitate this movement. ${ }^{13}$

${ }^{12}$ On Bonaventure's affective or voluntaristic view, see T. C. Potts, Conscience in Medieval Philosophy (Cambridge: Cambridge University Press, 1980) 32-44. On Summa naturali$u m$, see the following passages: 'Iste autem qui cognoscit sub ratione boni, dividitur, quia bonum aut est est universale aut particulare. Si universale, vocatur synderesis, quae semper movet ad bonum in universali et semper remurmurat malo'. (Summa naturalium Tr. V, c. 8, edited by B. Geyer in Die Albert dem Grossen zugeschriebene Summa Naturalium [Philosophia Pauperum], Texte und Untersuchungen, Beiträge zur Geschichte der Philosophie und Theologie des Mittelalters, Texte und Untersuchungen 35, Heft 1 [Münster: Aschendorff, 1938] 58*, 40-59*, 1); 'Summum quod est in ea in movendo, dicitur synderesis et stat in universali...Synderesis autem, ut dictum, est in motiva'. (Tr. V, c. 8, ed. Geyer 60*, 27-28; 31-32); ' ...differt [scil. intelligentia] a synderesi, quoniam synderesis nihil deliberat, illa bene deliberat. Item synderesis sicut est affectiva communiter in bonum, ita est communiter detestiva mali. Unde semper remurmurat malo'. (Tr. V, c. 8, ed. Geyer 61*, 4-7). Peyligk refers to Summa naturalium (which he believed to be written by Albert the Great) soon after the passages at hand (Compendium, fol. $\mathrm{P} 2^{\mathrm{v}} ; \mathrm{P}^{\mathrm{r}}$ ).

${ }^{13}$ Peyligk, Compendium, fol. P2 ${ }^{\mathrm{r}}$ : 'Animae sunt duo habitus concreati: intellectus quo materialiter cognoscit principia speculativa, sinderesis quo materialiter cognoscit principia practica. Unde secundum beatum Thomam p. 1 q. 1xxix ar. xii sinderesis non nominat potentiam sed habitum'. On Aquinas, see Potts (1980) 45-60. 
The view Peyligk ascribes to Aquinas is roughly the same as that of a contemporaneous Cologne Thomist, Lambert of Heerenberg. ${ }^{14}$ According to him, synderesis is

in the rational soul, not as a power, but as a disposition... since synderesis denotes a disposition for assenting to the practical principles or in the matters of action...therefore synderesis is in the practical intellect for assenting practical principles...such as this principle: every good is to be done... and this act [of conscience] derives from synderesis, in virtue of which the intellect itself turns to the highest. ${ }^{15}$

Although Lambert does not explicitly deny the possibility that synderesis could be understood a moving power, it seems clear that compared to Peyligk, Lambert's position is far more cognitive, and therefore closer to Aquinas in this particular matter. He gives an example of practical principles, but does not mention the practical syllogism in this context and does not discuss the question of whether synderesis is a disposition of reason or one of will. Although Peyligk does not refer to the Thomists of his time, a certain vagueness in Lambert's position makes it understandable why Peyligk could consider this kind of view as compatible with his own. ${ }^{16}$

${ }^{14}$ On the importance of Cologne Thomism for Leipzig Thomists, see Tewes (1995) 457-58.

${ }^{15}$ Lambertus de Monte Domini, Expositio circa tres libros De anima Aristotelis iuxta doctrinam Thomae Aquinatis cum textu (Cologne, 1498), fol. $70^{\mathrm{v}}$ : 'Dicendum quod ista [scil. synderesis et ratio] ponuntur in anima rationali non sicut potentiae, sed sicut habitus vel actus, quia synderesis nominat habitum assensivum primorum principiorum in practicis vel agibilibus... sic synderesis ponitur in intellectu practico ad assentiendum principiis practicis...sicut illi principio: omne bonum est faciendum...et ille actus [scil. conscientiae] oritur ex synderesi secundum quam ipse intellectus deprecatur ad optima'.

${ }^{16}$ For a more straightforwardly Thomist view of synderesis by Peyligk's contemporary in Leipzig, see Magnus Hundt, Introductorium in Aristotelis physicen, parvulus philosophiae 
In contrast to Peyligk's position - which may be characterized as affective, with the exception to the incorporation of Aquinas's understanding of synderesis as a cognitive disposition - Usingen presents a view that is thoroughly cognitive:

Synderesis is a power by which we judge the good to be pursued and evil to be avoided in a general and universal sense, since it deals with things to be done, that is, the things belonging to the realm of praxis, like the following: 'every good is to be done and every evil to be avoided'...So synderesis does not err concerning the principles of operation and therefore it is said to provide the major premiss in the practical syllogism. It is also possible to understand synderesis as to refer to the disposition which makes the soul accept the first principles of operations.

According to Usingen, then, synderesis is an intellectual faculty of the soul which provides moral reasoning with universal principles, such as 'every good is to be done and every evil is to be avoided'. These principles constitute the first step in moral reasoning, which Usingen describes by means of the Aristotelian idea of the practical syllogism. According to this view, moral reasoning follows a structure formally similar to the syllogistic structure of speculative reasoning. Therefore every moral judgement can be analysed into two premises and a conclusion inferred from these. Synderesis provides the first premiss, which is always a universal proposition. Usingen thus views the function of synderesis purely in an cognitive manner like Aquinas, and even similarly applies the theory of the practical syllogism. The main difference compared to Aquinas is that Usingen considers synderesis metaphysically as a faculty (po-

naturalis vulgariter appellatum cum propria non extranea declaratione (Leipzig, 1500) fol. A3r. 
tentia) of the human intellectual soul, a view Aquinas explicitly denies. Instead, Aquinas defines synderesis as an innate disposition to know the basic principles of morality (and Usingen actually admits this to be one meaning of the concept).

The obvious similarities to Aquinas, however, do not endanger Usingen's identity as a representative of the via moderna in his context. Pierre d'Ailly, who was one of the undisputed authorities of the via moderna, had introduced a similar view of synderesis and practical syllogism a hundred years earlier in his Tractatus de anima. ${ }^{17}$ Its structure is formally very close to that found in book 2 d. 24 of Aquinas's Sentences commentary, ${ }^{18}$ even regarding the choice of terminology. Baylor also describes a rather similar view in the writings of Gabriel Biel and notices the similarities to Aquinas. ${ }^{19}$

So far, the following (somewhat awkward) conclusion about the two authors' differing views on synderesis can be made: a modified version of Aquinas's view can be found in the standard view of the via moderna, represented by Usingen; another view, which can be identified as a voluntarist theory, forms the basis of Peyligk's exposition. As stated above, Peyligk seems to follow the views on moral psychology that were presented by the author of the Summa naturalium. In addition to interpreting synderesis in a voluntaristic manner, this textbook does not bring the practical syllogism into the discussion on faculties of moral psychology. Neither does Peyligk, even if the idea of practical syllogism is central to Aquinas's moral psychology. Furthermore, Peyligk explicitly quotes in the same passage the definition

\footnotetext{
${ }^{17}$ Pierre d'Ailly, Tractatus de anima, c. 6, p. 4, edited by O. Pluta in Philosophische Psychologie des Peter von Ailly (Amsterdam: Grüner 1987) 37.

${ }^{18}$ Thomas Aquinas, Scriptum super libros Sententiarum II.24.2, art. 4 co.

${ }^{19}$ Baylor (1977) 98.
} 
of the liberum arbitrium from the Summa naturalium. Thus similarities to the Summa naturalium seem, at least in this small passage, rather strong. ${ }^{20}$

Therefore, even if Usingen and Peyligk were commenting on the same basic text, the Parvulus philosophie naturalis, their interpretations are based on different authorities. That leads us to ask whether their choice of authorities reflects their affinities to the different philosophical schools. A similar case found in the teaching of natural philosophy in late $15^{\text {th }}$ century Tübingen suggests for a positive answer. Gabriel Biel, who was the professor of theology in the chair of the via moderna, has left us a manuscript containing a commentary on Pierre d'Ailly's Tractatus de anima. ${ }^{21}$ And, Conrad Summenhart, who held the chair of the via antiqua at the same time in Tübingen, wrote a commentary on the Summa naturalium, which has survived even in printed form. ${ }^{22}$

Such a choice of authorities was somehow quite natural for both viae. D'Ailly's tractate was in fact a revision of the Summa naturalium, or at least was very much based on it. ${ }^{23}$ Even if d'Ailly had adopted some elements familiar to Thomist psychology, he was still one of the more recent authors and belonged to the same camp as William of Ockham. The philosophers of the via antiqua, for their part, turned back to earlier authorities such as the Summa naturalium, which was thought to be written by Albert the Great and which was widely used in Germany before Pierre d'Ailly wrote his treatise. However, the fact that d'Ailly used the Summa naturalium as a basis for his treatise is reflected in the relative mutual uniformity of Usingen's and Peyligk's interpretations. Even the very discussion of the faculties of moral

${ }^{20}$ Peyligk, Compendium, fol. P2 .

${ }^{21}$ Gabriel Biel, Commentarium in tractatum de anima Petri de Aillyaco, see Pluta (1987) 5.

${ }^{22}$ Conrad Summenhart, Commentaria in summam physice Alberti Magni (Hagenau, 1507).

${ }^{23}$ On d'Ailly's Tractatus and Summa naturalium, see K. Park, 'Albert's Influence on Late Medieval Psychology', in Albertus Magnus and the Sciences, edited by J. A. Weisheipl (Toronto: Pontificial Institute of Mediaeval Studies, 1980) 519-21. 
psychology would not self-evidently find itself in a late medieval commentary on Aristotelian psychology. The inclusion of this topic is due rather to the common tradition shared by d'Ailly and the Summa naturalium, which dates back to the natural philosophy of Albert the Great.

\section{Jodocus Trutfetter and the Twofold Synderesis}

Usingen's view on synderesis did not change in his later publications on natural philosophy in 1507 and 1517 . The only significant change seems to be that he abandoned the possibility of understanding the synderesis in the sense of a disposition, thus sharpening the difference with the Thomist view. ${ }^{24}$ His colleague in Erfurt, Jodocus Trutfetter, also published a natural philosophy in 1514 and consequently presents a view on synderesis which is in general terms similar to that of Usingen. However, Trutfetter discusses the diverse views on the matter at somewhat greater length than Usingen did. He notes that philosophers have different views on whether synderesis and related terms should be understood as denoting cognitive or voluntary powers, or even dispositions or acts of mental powers. Trutfetter himself advocates the view of the via moderna, which considers synderesis as a power and not as a disposition, and specifically a cognitive power. He mentions the principle of parsimony as a basis for rejecting the necessity to posit an innate disposition in this context. ${ }^{25}$

\footnotetext{
${ }^{24}$ Usingen, Compendium, fols. $\mathrm{M}^{\mathrm{v}}-\mathrm{N} 1^{\mathrm{r}}$; Compendium naturalis philosophiae totius (Erfurt, 1517), fol. N4 ${ }^{\mathrm{v}}$.

${ }^{25}$ Trutfetter, Summa in totam physicen [Summa] (Erfurt, 1514), fol. Ff4 ${ }^{\mathrm{r}}$.
} 
With an explicit reference to Biel, Trutfetter considers synderesis to mean the power to assent to practical principles 'or an innate disposition to assent, if that should be posited' ${ }^{26}$ Through this remark Trutfetter attributes some plausibility to a rival Thomist view. This is reminiscent of Usingen's remarks in the Parvulus, but like Usingen, Trutfetter considers it unnecessary to posit an innate disposition. In contrast, the view of synderesis as an acquired disposition or as an act is straightforwardly rejected. Such notions are clearly disregarded on the basis that synderesis as a term relates to a permanent and indissoluble capability, whether or not actualized at a certain time. ${ }^{27}$

Trutfetter's convergence towards contemporaneous views of the via antiqua is not restricted to a certain tolerance of the idea of an innate disposition, but rather goes further into the tradition of affective synderesis. Trutfetter admits that the term 'synderesis' may be used 'in a sense denoting inclination (inclinative)' to concern a power that moves and consequently 'by this one may easily solve many questions and bring together the controversies that are found among the sayings of different teachers on these matters'. Trutfetter's remark may refer to the disagreement between Aquinas and Bonaventure, which Biel relates at the beginning of his discussion on synderesis. ${ }^{28}$

${ }^{26}$ Trutfetter, Summa, fol. Ff4ㄴ: ‘ ...vel habitus innatus ad sic assentiendum inclinans, si ponitur'.

${ }^{27}$ Trutfetter, Summa, fol. Ff4 ${ }^{\mathrm{v}}$.

${ }^{28}$ Trutfetter, Summa, fol. Ff5' : 'Potest itaque dici synteresim et conscientiam ostensive seu dictative pertinere ad vim cognoscitivam seu intellectivam, inclinative autem ad motivam sive appetitivam. Et his dissolvi facile possunt multae quaestiones et concordari contraversiae quae inter doctores de hac materia loquentes inveniuntur'. See also Summa, fol. Ff4 ${ }^{\mathrm{v}}$ : 'Et iterum singulis his naturalibus inclinationibus potentiis, actibus et habitibus in intellectu practico ad assentiendum respondent pariter in vi motiva sive appetitiva (id est voluntate) consimiles inclinationes naturales, actus, habitus et potentiae ad acceptandum, volendum, prosequendum et exequendum (ubi facultas affuerit) iudicatum bonum vel conveniens, vel refutandum, nolendum et fugiendum iudicatum malum et disconveniens, quae etiam $\mathrm{qu}[\mathrm{u}] \mathrm{m}$ non habeant specialia nomina ipsis instituta priorum nominibus vocitamus'. 
Trutfetter's view echoes that of the early Franciscan Alexander of Hales, who considered synderesis as belonging to both reason and will. Trutfetter refers to Alexander's Summa in his discussion on conscience, although he does not explicitly mention Alexander in the context of synderesis. ${ }^{29}$ Therefore there are good reasons to assume that Trutfetter's harmonization of different scholastic views derives from the roots of the two major medieval traditions of synderesis, both of which ultimately date back to the Parisian theologian Philip the Chancellor. ${ }^{30}$ In comparison to Usingen's initial and even later view, it may be stated that Trutfetter, without leaving the shared position of the via moderna, is showing a considerable amount of openness towards views which differ from his own. By adopting the dual concept of synderesis, Trutfetter's view converges significantly with the position represented by Peyligk, which combined the basic view of affective synderesis with Aquinas's exclusively cognitive notion. ${ }^{31}$

For Biel, see Collectorium in quattuor libros Sententiarum II.39.B-C, edited by W. Werbeck \& U. Hoffmann (Tübingen: J.C.B. Mohr, 1984) 656-57.

${ }^{29}$ Trutfetter refers to Alexander of Hales's, Summa theologica II.77 and 137. See Trutfetter, Summa, fol. Ff6 ${ }^{\mathrm{v}}$. Alexander discusses synderesis in Summa theologica II.76. For the text, see D. O. Lottin, Psychologie et morale aux XIIe et XIIIe siecles (Louvain: Abbaye du Mont César, 1948): II.1, 179, fn. 3 and 4. Baylor also notes Alexander's notion of twofold synderesis (Baylor (1977) 28, fn. 34). Trutfetter's terminology further resembles a passage in Georg Reisch's Margarita philosophica: 'Et hoc si tenere placuerit ea qui sinderesim et conscientiam voluntati tribuenda arguunt, quia sinderesis remurmurat malo et conscientia remordet, intelligenda sunt ostensive et dictative et quodammodo inclinative sine tamen coactionis necessitate'. Georg Reisch, Margarita philosophica 10.11, fol. b (Strasbourg, 1508). Trutfetter also refers favourably to his contemporary Reisch in Summa, fol. Y $4^{\mathrm{r}}$.

${ }^{30}$ On Alexander's reliance on Philip, see Lottin (1948) 179. On Philip, see also ibid. 138-57.

${ }^{31}$ Consideration of Trutfetter's view renders Baylor's claim (Baylor (1977) 157; 160-62), according to which Luther's idea of synderesis of reason and will marks a significant departure from the scholastic view, extremely problematic. Unlike earlier authors, whom Baylor refers to, Trutfetter had some kind of notion of synderesis as a power that is both affective and cognitive at the same time. It should be noted, however, that the similarities between Luther and Trutfetter reaffirm Baylor's claim (Baylor (1977) 167) that the notion of a dual synderesis was discussed in the context of the via moderna. 
In 1517 Trutfetter published a shortened version of his natural philosophy and, apart from the omission of certain parts, developed his view a bit further. He starts the consideration of synderesis by defining it as actual knowledge of or assent to the principles of morality, but eventually considers the most proper notion of synderesis as an inclination of the intellect, one which is identical to the intellect itself and is not a disposition in the intellect to assent to the principles. Even this formulation does not explain much of the genesis of the principles themselves, which might be considered as a weak point of the position. Despite this, Trutfetter is not willing to accept the notion of an innate habit. Furthermore, according to Trutfetter, this notion is most compatible with the corresponding notions in the Scriptures, such as the apex mentis and the "inextinguishable spark of reason." ${ }^{32}$ Although Trutfetter's remark that in the Scriptures some qualities are attributed to synderesis seems a little farfetched, since the term itself is not found in the Bible, it correctly reflects the historical roots of the concept, which are found in Jerome's exegesis of Ezechiel's vision. ${ }^{33}$

\section{Martin Luther and Synderesis}

The earliest traces of Luther's views on synderesis are found in his marginal notes on Peter Lombard's Sentences, composed in Erfurt during the years 1507-11. In his comments on Book 2, dist. 39, where synderesis was traditionally discussed, Luther presents thoughts which would seem to hint at the idea of an affective synderesis:

\footnotetext{
${ }^{32}$ Jodocus Trutfetter, Summa philosophiae naturalis contracta (Erfurt, 1517), $\mathrm{X}^{\mathrm{r}-\mathrm{v}}$.

${ }^{33}$ For Jerome, see Potts (1980) 6-11.
} 
Therefore the intellect, insofar as it is, is true and does not cease naturally to incline to the true, as long as it has being which is not intellectually obstructed, when it is vitiated with falsity. And similarily the will for as long as it remains being in itself, it is not able, according to this being, not to incline to good, although according to its corrupted being it is inclined to evil. And this is the same will. ${ }^{34}$

Firstly, it should be noted that Luther does not mention synderesis in his comments on the distinction, and much less the question of whether synderesis should be considered as a cognitive or an affective power, which was the only question posed by Biel in the corresponding distinction. Even if synderesis was commonly discussed in the context of this distinction, it should be noted that Peter Lombard himself does not use the term. Secondly, Luther's remarks belong to an explication of Lombard's text which describes an anonymous opinion according to which the will wants good and evil simultaneously in one act. Luther solves this apparent self-contradiction by applying the notion of evil as a mere privation of goodness. The permanent inclination of the intellect towards the true and corresponding inclination of the will towards the good is thus equated with the being of the intellect and will qua being, since in metaphysical terms the corrupted being qua corrupted has no positive being at all. ${ }^{35}$

Luther seems here to take it for granted that intellect and will are attributed to some form of natural inclination towards truth and good, respectively. This may not be so much an indication of Luther's preference for an affective synderesis than simply due to the question

\footnotetext{
${ }^{34}$ Martin Luther, D. Martin Luthers Werke. Kritische Gesamtausgabe (Weimar: Hermann Böhlau, 1883-) [WA] 9, 79, 16-21 (transl. M. Baylor), see Baylor (1977) 166-68.

${ }^{35}$ For Luther's view of evil as a privation of goodness in the marginal notes on Peter Lombard, see P. Kärkkäinen, 'Martin Luther', in Medieval Commentaries of the Sentences of Peter Lombard, Vol. II, edited by Ph. W. Rosemann (Leiden: Brill, 2010) 484-5.
} 
posed by Peter Lombard, which presupposes such a natural will to the good, and further inquires as to how this is compatible with the will's tendency towards evil, which results from original sin. As in many other parts of his marginal notes, Luther seems to devote a relatively large amount of attention to the original text of Peter Lombard and neglects the questions discussed by the commentators. Regarding the notion of synderesis, it is noteworthy that the solution Luther proposes here includes an idea of a permanent inclination of reason and will towards truth and good. This notion is only a small step away from identifying the will's inclination towards good with the traditional notion of affective synderesis, which would clearly mark a difference compared to the nominalist views of Biel and Usingen. ${ }^{36}$ However, Luther did not make this step in his early marginal notes and therefore his view does not yet show a significant divergence from the common understanding of the via moderna. Moreover, an explicitly cognitive notion of synderesis is manifest in his subsequent writings up until 1514, when we find a concept of dual synderesis similar to the one found in Trutfetter's Summa. $^{37}$

In a sermon on the Feast of St. Stephen, given a few months ${ }^{38}$ after the publication of Trutfetter's Summa, Luther speaks of a twofold synderesis:

This synderesis in the will of man remains forever, for it wishes to be saved and to live well and beautifully; it does not desire, and hates to be damned, and thus the syn-

${ }^{36}$ Baylor sees here also notion of cognitive synderesis, but an inclination towards truth was not considered by Biel or others as synderesis, but an inclination towards good or knowledge of the principles of practical reason, although Biel considered it as power of the intellect and not that of will. See Baylor (1977) 166; Biel, Collectorium, 2.39.D 22-27; E 1-3; F 14-15.

${ }^{37}$ On Luther's references to synderesis in early lectures on Psalms (1513-15) and Romans (1515-16), see Baylor (1977) 128-44.

${ }^{38}$ On dating of the sermon, see Luther, WA 59, 333. 
deresis of the reason pleads inextinguishably for the best, the true, the right, and the just. For this synderesis is a preservation, a remainder or a left-over portion of our nature in the corruption and faultiness of perdition. It is like a tinder, a seed and the material of our future revival and the restoration of our nature through grace. ${ }^{39}$

In Luther's account the cognitive 'synderesis of reason' is described in philosophical terms, whereas 'synderesis of the will' belongs to a specifically theological application of the philosophical notion which here gives a name to the natural will to be saved. The focus is on the idea that the will to salvation is originally in conformity with God's good will towards humans and as synderesis of will it is also part of the natural constitution of a human being. While being good in itself, this synderesis also has another nature, which becomes apparent in Luther's remark on the distortion of the will. When the impious resist grace, they do this by relying on their synderesis. Synderesis is therefore at the same time a kind of basis in human nature for one's salvation through grace, but, being good in itself, it is also a potential resource for damnation, when taken into the service of distorted human will. This ambiguity may be connected to the definition of synderesis which posits a particular good (of one's own salvation) as an object of the will's inclination. In general, therefore, Luther's theological application extends far beyond Trufetter's more terminological remarks, but still seems to be derived from similar roots. ${ }^{40}$

${ }^{39}$ Luther, WA 1, 32, 1-6. Transl. by M. Baylor in Baylor (1977) 158.

${ }^{40}$ Luther, WA 1, 32, 14-18: 'Resuscitabilis itaque est natura, nisi ponatur obex et gratiae resistatur, quod faciunt impii, qui freti sua Synteresi et prae voluntate ac sapientia propria nolunt restaurari, sed sani sibi videntur. Igitur adeo radicaliter ista portio voluntatis inest, ut etiam in damnatis sola sit causa totius pene inferni, quod nolunt eum et volunt contrariam salutem inaestimabili vehementia'. See Baylor (1977) 181-82. 
It was certainly affective synderesis which soon became for Luther the most problematic part of the concept of synderesis. The fundamental change seems to have taken place in Luther's attitude towards the notion of synderesis during the Lectures on Romans. ${ }^{41}$ Even if it is somewhat unclear which was the exact target of Luther's critical tones against synderesis, it seems most obvious that the uneasiness with the concept was related to the volitional side of the human mind. ${ }^{42}$

In the marginal notes on Biel's Collectorium, Luther already rejects the view that the will, referred to as rational desire (appetitus rationalis), would be by nature directed towards the highest good. Instead, Luther considers the view which Biel rejects to be more appropriate. According to it, the will naturally seeks only its own good, which is in fundamental contradiction with considering God as the highest good. ${ }^{43}$ At first sight it is not perfectly obvious whether Luther would consider this to be incompatible with the idea of the synderesis of will as described in the sermon from 1514, since also here natural will is directed towards the

${ }^{41}$ Baylor (1977) 173-75. Baylor does not share the earlier standard interpretation according to which the reason for Luther's later negative attitude would be the semi-Pelagian notion embedded in the scholastic view of synderesis (ibid. 178). He also rejects Ozments's version of the explanation, as well as Hirsch's suggestion that the reason for the rejection was that synderesis was an unbiblical notion. Baylor himself connects the change to Luther's evolving concept of conscience as a faculty which overshadows and absorbs in itself the former notion of synderesis (ibid. 202-8). Baylor's explanation is not, however, very clear about the reasons for Luther's criticism of certain notions of synderesis and why this criticism would not, together with the fact that the term does not appear in the Bible, play a part in Luther's eventually dropping of the term from his vocabulary.

${ }^{42}$ See how Luther relates synderesis to loving God above all things (Luther, WA 56, 275, $17-$ 23). Such a connection is not easy to find among previous views, including Scotus and Biel (see Grane (1962) 224). Neither does Trutfetter in his natural philosophy relate synderesis to loving God above all things.

${ }^{43}$ Luther approves of this argument which Scotus and Biel reject (quoted according to Biel, Collectorium, 3.27.Q 5-9): 'Sed in oppositum est, 'quia natura determinatur ad unum. Determinatur autem ad appetendum esse proprium, II De generatione; ergo non potest appetere sui non esse', etiam quocumque posito. 'Quaecumque ergo natura intellectualis magis determinatur ad appetendum se esse quam ad appetendum Deum esse, si non posset utrumque simul stare.' See Luther, WA 59, 45, 29-31. See also Grane (1962) 357-58. 
good. In the sermon the good was in some sense even considered as a particular good, namely one's own salvation. However, the idea of universality, which is closely linked to the notion of synderesis, is missing in Luther's marginal notes. In the sermon from 1514 this aspect was in a way present through the idea that the particular will for salvation was considered as being in conformity with God's universal will for the salvation of all humans. So it seems clear that Luther's view of natural will in the marginal notes is already in contradiction with any idea of a synderesis of the will. It would be unlikely that the natural will of the human being, seeking its own particular good, which is furthermore contrasted with loving God above all things, could be called in any traditional sense synderesis. Even if one would not like to see a contradiction between Luther's views in the aforementioned writings, it seems obvious that Luther's theological notion of affective synderesis had developed in a direction that was so far from the traditional usage of the term that its gradual dissappearence and integration into the more biblical notion of conscience seems natural. ${ }^{44}$

5. Johannes Bernhardi: synderesis between scholasticism and Lutheranism

While Luther eventually ceased to use synderesis in his theological writings, the term seems to be retained in the philosophical teaching of other Wittenberg reformers. After a relatively quiet period with respect to the teaching of ethics and natural philosophy in the $1520 \mathrm{~s}$, Melanchthon forcefully reintroduced these subjects to the university curriculum, which also resulted in several publications during the following decades. ${ }^{45}$ The earliest publication on Ar-

\footnotetext{
${ }^{44}$ On the disappearence of synderesis from Luther's theology, see Baylor (1977) 173-208.

${ }^{45}$ S. Kusukawa, The Transformation of Natural Philosophy: the Case of Philip Melanchthon (Cambridge: Cambridge University Press, 1995).
} 
istotelian psychology from a Wittenberg reformer was In philosophiae naturalis partem omnium praestantissimam, hoc est Aristotelis de Anima libros, epitome longe doctissima Epitome by Johannes Bernhardi of Feldkirch (Johannes Velcurio), which was posthumously printed in Basel in 1537. The treatise seems to be based on the lectures which Bernhardi gave in Wittenberg before his untimely death in $1534 .^{46}$

Bernhardi's commentary follows the form of a scholastic compendium to an astounding degree, adding, however, a considerable number of quotations from ancient authors. The general outline of the work is very similar to Trutfetter's natural philosophy, but Bernhardi never refers to any of the scholastic sources, unlike Melanchthon, who recommends both Bernhardi and Trutfetter in the dedicatory letter of his Commentarius de anima several years later. $^{47}$

Bernhardi discusses synderesis, reason and conscience, in the same way as his scholastic predecessors, in the context of the practical intellect. He precedes his discussion of these topics by including a chapter on the law of nature. He remarks, however, that these topics actually belong to the introductory material for ethics and that they are also useful for theologians. $^{48}$

In comparing Bernhardi's position to that of the Erfurtians, its most striking feature is its affinity to the view of Thomas Aquinas. Bernhardi defines synderesis as

${ }^{46}$ Johannes Bernhardi of Feldkirch, In philosophiae naturalis partem omnium praestantissimam, hoc est Aristotelis de Anima libros, epitome longe doctissima Epitome [Epitome] (Basel, 1537). On the publication history of the work, see Kusukawa (1995) 109-13. A description of a comet in 1531 marks a terminus post quem for the treatise. See the first edition of Bernhardi's whole work, which contains also the astronomy, Epitomae physicae libri quattuor VIII.2 (Erfurt, 1538), X6 ${ }^{\mathrm{V}}$.

${ }^{47}$ Philip Melanchthon, Commentarius de anima [Commentarius] (Wittenberg, 1540), a5r.

${ }^{48}$ Bernhardi, Epitome 26, p. 53-4. 
the natural disposition (habitus) of practical moral principles, as if it were (quasi) created in the human being, turning towards the law of nature, which it observes, inciting the human being to good and murmuring against evil...an innate disposition, observing the moral or practical principles, whose function is to provide the major premiss of the practical syllogism, derived from the law of nature, and its proof. ${ }^{49}$

Bernhardi then unequivocally adopts the view of synderesis as an intellectual disposition, which was rejected by Trutfetter as an improbable view. On the other hand, Bernhardi's view is thoroughly intellectualistic, and as such he comes closer to Lambert than Peyligk among the Thomist thinkers, although Bernhardi does not completely reject the voluntarist reading of the concept. To the contrary, he leaves it an open question as to whether synderesis could be understood as a innate disposition of the will or not. The contrast with the view of the via moderna, which considered synderesis as a faculty, seems sharper than the contrast with the voluntarist or affectualist tradition of the via antiqua. ${ }^{50}$

However, there seems to be no need for positing a particularly Thomist influence as a source of Bernhardi's view. He might have considered the notion of an innate habit (which even Trutfetter did not entirely reject) to be more compatible with his idea of principles of morality as innate notions than the nominalist view of synderesis as the power to assent to the principles. Even if Trutfetter as well considered principles of morality as universally valid sentences, Bernhardi's discussion of the naturally known principles seems to be more reminiscent of his teacher Melanchthon, who adopted the Ciceronian-Stoic terminology of no-

\footnotetext{
${ }^{49}$ Bernhardi, Epitome 27, p. 54.

${ }^{50}$ Bernhardi, Epitome 27, p. 55.
} 
tiones naturales already in his Loci praecipui theologici from 1521 to explain the natural knowledge of moral law. ${ }^{51}$

One peculiar feature in Bernhardi's discussion of synderesis is the prominent position of natural law. This reveals a further affiliation to Thomist views, but such a notion was not completely foreign to Trutfetter either. In an explication of the function of synderesis in providing the major premiss of the practical syllogism, Bernhardi gives an example that the proof of a major premiss (in this case 'fidelity is to be observed') is based on the Golden Rule: 'Do not do to others what you do not want to be done to you'. The same rule appears in both positive and negative forms in Trutfetter's discussion of natural law, although he does not yet explicitly connect it to synderesis. ${ }^{52}$ The idea of the Golden Rule as the content of natural law was also frequently repeated by Luther, but not found in Melanchthon. ${ }^{53}$

Bernhardi's work was reprinted 21 times until 1595, including two printings in London (1572 and 1588). ${ }^{54}$ The 1539 Tübingen printing was edited by one of Bernhardi's students, Selbald Havenreuther, whose son Johann Ludwig later published a natural philosophy as well. ${ }^{55}$ Along with Havenreuther's Compendium librorum physicorum, Bernhardi's natural

${ }^{51}$ On Bernhardi's view of the naturally known principles in general, see Epitome 32, p. 62 and on moral principles in particular, see Epitome 34, pp. 63-64. On Melanchthon, see G. Frank Die theologische Philosophie Philipp Melanchthons (1497-1560) (Leipzig: Benno, 1995) 112-16, esp. 116, fn. 275.

${ }^{52}$ Bernhardi, Epitome 29, p. 57, Trutfetter, Summa philosophiae naturalis contracta, X3 ${ }^{\mathrm{r}}$.

${ }^{53}$ A. Raunio, Summe des christlichen Lebens. Die "Goldene Regel" als Gesetz der Liebe in der Theologie Martin Luthers von 1510-1527 (Mainz: Philipp von Zabern, 2001) 159-63; 302-5; ibid., 'Natural Law and Faith: The Forgotten Foundations of Ethics in Luther's Theology', in Union with Christ. The New Finnish Interpretation of Luther, edited by Carl E. Braaten \& Robert W. Jenson (Grand Rapids: Eerdmans, 1998) 105-8 and ibid., 'Divine and Natural Law in Luther and Melanchthon' in Lutheran Reformation and the Law, edited by Virpi Mäkinen (Leiden: Brill, 2006) 33-54.

${ }^{54}$ C. H. Lohr, 'Renaissance Latin Aristotle Commentaries: Authors So-Z', Renaissance Quarterly 35 (1982) No. 2: 212.

${ }^{55}$ Kusukawa (1995) 112. 
philosophy was the most elaborate of the continental introductory textbooks on natural philosophy which appeared in large numbers from English printing houses from the 1570s until the $1590 \mathrm{~s} .{ }^{56}$ Even as late as in 1621 Robert Burton cites Bernhardi's views extensively in his Anatomy of Melancholy, among them his view on synderesis. ${ }^{57}$

6. Melanchthon and the transformations of the synderesis

In the introductory letter of his Commentarius de anima from 1540, Melanchthon suggests, in addition to the Spanish humanist Juan Luis Vives, both Trutfetter ('Isennacensis') and Bernhardi ('Velcurio') as further reading, whereas he describes his own commentary merely as a short introduction to the topic. In the light of this remark, it seems natural to relate Melanchthon's view on synderesis to the authors mentioned above. ${ }^{58}$

Melanchthon's brief definition of synderesis sharpens the cognitive aspect and the connection to the natural law already present in Bernhardi: 'Synderesis signifies the conservation of the knowledge (notitia) of natural law, which is innate to us (quae nobiscum nascitur) ${ }^{59}$ The idea of natural notions, central to Melanchthon's philosophy in general, is used in a similar way as in Bernhardi. ${ }^{60}$ The metaphysical status of synderesis remains therefore somewhat vague in terms of traditional terminology, since on the one hand Melanchthon does

${ }^{56}$ C. B. Schmitt, John Case and Aristotelianism in Renaissance England (Kingston: McGillQueen's University Press, 1983) 68-69.

${ }^{57}$ Robert Burton, The Anatomy of Melancholy, edited by Th. C. Faulkner et. al., (Oxford: Clarendon, 1989) Vol. 1, 1.1.2.11 (p. 159).

${ }^{58}$ Melanchthon, Commentarius, fol. a $5^{\mathrm{r}}$.

${ }^{59}$ Melanchthon, Commentarius, fol. d7(215) ': 'Synteresis significat conservationem notitiae legis, quae nobiscum nascitur'.

${ }^{60}$ On Melanchthon's view of natural notions, see Frank (1995) 112-58; on its relevance to knowledge of natural law, see in particular 144-5. 
not explicitly call it a habitus, as Bernhardi did, yet on the other the notion of an innate disposition is not rejected in favour of a faculty, as was the case in the via moderna represented by Trutfetter. It seems that Melanchthon reserved the term habitus to mean an acquired disposition. $^{61}$

If Melanchthon's wording would be interpreted through Trutfetter's traditional terminology, synderesis as knowledge (notitia) would actually mean an operation (actus) of the mind. This was indeed the first meaning that Trutfetter gave to the term synderesis in his discussion of the concept in 1517. However, it is not clear whether Melanchthon distinguishes here between actual and dispositional knowledge, although the use of the term "conservation" could refer to such a distinction. Furthermore, if knowledge of natural law were interpreted as a shorthand version of the mind's natural capability to know precepts of the natural law, Melanchthon's view is eventually rather close to that of Trutfetter. For the idea of natural notions, however, there is no exact correspondence in the system of the via moderna; actually, Trutfetter discards the conception of species concreatae and the Platonist doctrine of anamnesis of Forms with reference to Aristotle's view, according to which the human mind is initially a blank slate. ${ }^{62}$ However, in 1514 he admits that there exists an innate 'ray of the first truth in the mind, which comprises the forms and notions of all things, by which we judge things which we have never learned'. ${ }^{63}$ Such a remark appears in Trutfetter only incidentally and does not reappear in the shortened 1517 version of the work. In contrast, both Luther and Melanchthon seem to have adopted a notion of the human mind's sharing the properties of

${ }^{61}$ Melanchthon, Commentarius, fol. g4 $(236)^{\mathrm{r}}-\mathrm{g} 6(238)^{\mathrm{r}}$.

${ }^{62}$ Trutfetter, Summa, Ee ${ }^{\mathrm{v}}$; Summa naturalis philosophiae contracta, $\mathrm{X} 1^{\mathrm{v}}$.

${ }^{63}$ Trutfetter, Summa, Ee4 ${ }^{\mathrm{v}}$ : 'Licet non infitiandum sit mentibus nostris inditum esse quandam radium primae veritatis omnium rerum species et notiones complicantem, quod etiam nonnunquam de his quae nunquam didicimus iudicamus; quantum enim lux illa in mente nostra efficiat quae ad imaginem ipsius creata est beatus Augustinus ... clare disseruit'. 
the divine mind as a permanent part of their theological and philosophical thinking. At least in the case of Melanchthon's discussion of synderesis this seems to provide a more comprehensive explanation of certain innate mental capabilities than the usual reference of the natural capabilities of the mental faculties in the via moderna. ${ }^{64}$

Melanchthon also mentions the practical syllogism in a favourable sense. Some echoes of Luther's way of incorporating synderesis into conscience may be traced in Melanchthon's remark that Paul refers to the entire argument (of the practical syllogism) and its conclusion as conscience. This is further justified by the fact that the major premiss is not always derived from natural knowledge of the law, but also from other parts of divine law, which could for Melanchthon mainly refer to the precepts known through the Scriptures.

In the discussion on affective synderesis Melanchthon follows along the same lines as Trutfetter and Bernhardi. Despite his emphatically cognitive definition of synderesis Melanchthon admits there are natural inclinations in the will, and these may also be called synderesis. However, he rejects the idea that such inclinations would be directed to loving God; they rather belong exclusively to the created sphere. In fact, the natural inclinations of the will are vicious in their relationship with divine things. ${ }^{65}$ Melanchthon's view is reminiscent of Luther's critical tones against some theological applications of the idea of affective synderesis, but at the same time it is more explicit in preserving the idea in the case of natural affections between humans.

In his Liber de anima from 1553 Melanchthon thoroughly revised the passage on practical intellect. He still discusses synderesis, but this time precedence is given to the concept of conscience, which is used, supported by the scriptural authority of St. Paul, to denote

\footnotetext{
${ }^{64}$ On Melanchthon, see Frank (1995) 112-24.

${ }^{65}$ Melanchthon, Commentarius, d8(216) ${ }^{\mathrm{r}}-\mathrm{e} 1(219)^{\mathrm{v}}$.
} 
the whole act of moral reasoning producing a judgement about the quality of particular actions. Melanchthon is quite clear in stating that conscience is not a faculty, but rather an operation of the faculty of reason. ${ }^{66}$ Synderesis is discussed briefly as a term used by theologians to mean 'knowledge of the law, which is innate in us'. In this context, Melanchthon refers to the practical syllogism, speaking continuously in the third person in order to indicate the distance from his own present view. At the end of the passage he remarks that St. Paul calls the entire practical syllogism 'conscience'. Thus in early Lutheran psychology in Wittenberg the history of synderesis ends as it seems to have done in Luther's theology, in the predominance of the Pauline concept of conscience. ${ }^{67}$

The early natural philosophy in Wittenberg therefore left two rather different accounts of synderesis. Both seem to build on, or at least are reminiscent of, Trutfetter's elaborated version of synderesis in the via moderna. Bernhardi and Melanchthon strongly emphasised synderesis as natural knowledge of the law, which probably led Bernhardi to consider synderesis as an innate disposition, thus echoing the traditional Thomist position. Both authors see synderesis as a predominantly cognitive phenomenon, but they also give credit to the idea of affective synderesis, although with some reservations. The idea seems to gradually disappear in Melanchthon's account, first in the rejection of a natural inclination to love God and finally in dissociating the discussion of the natural inclination of the will from the discussion of synderesis. $^{68}$

\section{Conclusion}

\footnotetext{
${ }^{66}$ Melanchthon, Liber de anima, in Melanchthons Werke in Auswahl edited by R. Nürnberger, vol. 3 [Liber de anima], 336.

${ }^{67}$ Melanchthon, Liber de anima, 337.

${ }^{68}$ Melanchthon, Liber de anima, 359.
} 
Above I have followed one line of interpretations of synderesis, starting from two scholastic commentaries of natural philosophy from 1499 and culminating in Melanchthon's Liber de anima fifty years later. Lessons can be learned from this piece of history, which comprises only one part of the discussion during that period of time. The comparison between Usingen and Peyligk shows that school traditions played an important role in the exposition of synderesis by the late medieval scholastic natural philosophers. However, Trutfetter's example warns against overemphasising the importance of the school traditions and reminds us of the manifold history of medieval discussions on synderesis, which were more or less familiar to many authors of this period. Finally, the diverse references to synderesis in the texts of Luther, Bernhardi and Melanchthon reveal no uniform relationship with late medieval discussions, but rather indicate various ways of adopting scholastic ideas and transforming them in the context of humanist and reformation thinking.

\section{Bibliography}

Baylor, M. Action and Person (Leiden: Brill, 1977).

Bernhardi, Johannes (of Feldkirch) In philosophiae naturalis partem omnium praestantissimam, hoc est Aristotelis de Anima libros, epitome longe doctissima Epitome (Basel, 1537). Bernhardi, Johannes (of Feldkirch) Epitomae physicae libri quattuor (Erfurt, 1538). Burton, Robert The Anatomy of Melancholy, edited by Thomas C. Faulkner et. al. 4 vols. (Oxford: Clarendon, 1989) Vol. 1.

Conrad Summenhart Commentaria in summam physice Alberti Magni. Hagenau, 1507. 
Frank, G. Die theologische Philosophie Philipp Melanchthons (1497-1560) (Leipzig: Benno, 1995).

Gabriel Biel Collectorium in quattuor libros Sententiarum, edited by W. Werbeck \& Udo Hoffmann (Tübingen: J.C.B. Mohr, 1984).

Grane, L. Contra Gabrielem: Luthers Auseinandersetzung mit Gabriel Biel in der Disputatio contra scholasticam theologiam 1517. København, 1962.

Hein, R. B. 'Gewissen' bei Adrian of Utrecht (Hadrian VI.), Erasmus von Rotterdam und Thomas More (Münster: Lit Verlag, 1999).

Hoenen, M. J.F.M. 'Via Antiqua and Via Moderna in the Fifteenth Century: Doctrinal, Institutional, and Church Political Factors in the Wegestreit', in The Medieval Heritage in Early Modern Metaphysics and Modal Theory, edited by L. Nielsen and R. Friedman (Dordrecht: Kluwer, 2003) 9-36.

Hundt, Magnus Introductorium in Aristotelis physicen, parvulus philosophiae naturalis vulgariter appellatum cum propria non extranea declaratione (Leipzig, 1500).

Kärkkäinen, P. 'Martin Luther', in Medieval Commentaries of the Sentences of Peter Lombard, Vol. II, edited by Ph. W. Rosemann (Leiden: Brill, 2010) 471-94.

Kusukawa, S. The Transformation of Natural Philosophy: the Case of Philip Melanchthon (Cambridge: Cambridge University Press, 1995).

Lalla, S. Secundum viam modernam: ontologischer Nominalismus bei Bartholomäus Arnoldi von Usingen (Würzburg: Königshausen \& Neumann, 2003).

Lambertus de Monte Domini Expositio circa tres libros De anima Aristotelis iuxta doctrinam Thomae Aquinatis cum textu (Cologne, 1498). 
Langston, D. Conscience and Other Virtues. University Park: The Pennsylvania State University Press, 2001).

Lohr, C. H. 'Renaissance Latin Aristotle Commentaries: Authors So-Z', Renaissance Quarterly 35 (1982) No. 2: 164-265.

Lottin, D. O. Psychologie et morale aux XIIe et XIIIe siecles Vol. 2 (Louvain, 1948).

Luther, Martin D. Martin Luthers Werke. Kritische Gesamtausgabe. Schriften (Weimar:

Hermann Böhlau, 1883-).

Melanchthon, Philip Commentarius de anima. Wittenberg, 1540.

Melanchthon, Philip Liber de anima, in Melanchthons Werke in Auswahl, edited by Richard Nürnberger (Gütersloh, 1969) Vol. 3.

Oberman, H. A. 'Via antiqua and Via Moderna: Late Medieval Prolegomena to Early Reformation Thought', Journal of the History of Ideas 48 (1987) No. 1: 23-40.

Oberman, H. A. 'Luther and the Via Moderna: The Philosophical Backdrop of the Reformation Breakthrough', Journal of Ecclesiastical History 54 (2003) No. 4: 641-70.

Park, K. 'Albert's Influence on Late Medieval Psychology', in Albertus Magnus and the Sciences, edited by J. A. Weisheipl (Toronto: Pontificial Institute of Mediaeval Studies, 1980) $519-21$.

Peyligk, Johannes. Philosophie naturalis compendium (Leipzig: Melchior Lotter, 1499). Pierre d'Ailly. Tractatus de anima, edited by Olaf Pluta in Pluta (1987).

Pluta, O. Philosophische Psychologie des Peter von Ailly (Amsterdam: Grüner, 1987).

Potts, T. C. Conscience in Medieval Philosophy (Cambridge: Cambridge University Press, 1980). 
Raunio, A. 'Natural Law and Faith: The Forgotten Foundations of Ethics in Luther's Theology', in Union with Christ. The New Finnish Interpretation of Luther, edited bt C. E. Braaten and R. W. Jenson (Grand Rapids: Eerdmans, 1998) 96-124.

Raunio, A. Summe des christlichen Lebens. Die "Goldene Regel" als Gesetz der Liebe in der Theologie Martin Luthers von 1510-1527 (Mainz: Philipp von Zabern, 2001).

Raunio, A. 'Divine and Natural Law in Luther and Melanchthon', in Lutheran Reformation and the Law, edited by V. Mäkinen (Leiden: Brill, 2006) 21-61.

Reisch, Georg. Margarita philosophica. Strasbourg, 1508.

Schmitt, C. B. John Case and Aristotelianism in Renaissance England (Kingston, McGillQueen's University Press, 1983).

Summa naturalium, edited by B. Geyer in Die Albert dem Grossen zugeschriebene Summa Naturalium (Philosophia Pauperum), Texte und Untersuchungen. Beiträge zur Geschichte der Philosophie und Theologie des Mittelalters, Texte und Untersuchungen 35, Heft 1 (Münster: Aschendorff, 1938).

Tewes, G.-R. 'Die Erfurter Nominalisten und ihre thomistischen Widersacher in Köln, Leipzig und Wittenberg. Ein Beitrag zum deutschen Humanismus am Vorabend der Reformation' in Die Bibliotheca Amploniana, edited by A. Speer (Berlin: Walter de Gruyter, 1995) 44788.

Thomas Aquinas Scriptum super libros Sententiarum (Parma, 1856).

Trutfetter, Jodocus Summa in totam physicen (Erfurt, 1514).

Trutfetter, Jodocus Summa philosophiae naturalis contracta (Erfurt, 1517).

Usingen, Bartholomaeus Arnoldi Parvulus philosophie naturalis (Leipzig, 1499).

Usingen, Bartholomaeus Arnoldi Compendium naturalis philosophie (Erfurt, ca. 1507). 
Usingen, Bartholomaeus Arnoldi. Compendium naturalis philosophiae totius (Erfurt, 1517). Zachmann, R. C. The Assurance of Faith (Louisville: Westminster John Knox Press, 1993). Zumkeller, A. Erbsünde, Gnade, Rechtfertigung und Verdienst nach der Lehre der Erfurter Augustinertheologen des Spätmittelalters (Würzburg: Augustinus-Verlag, 1984). 